\title{
An Assessment of Attitudes and Concerns of Residents towards Educational Scout-Based Tourism in Indonesia
}

\author{
Mufidah Afiyanti $^{* 1,3}$, Harsuko Riniwati ${ }^{2,3}$, Sri Wardhani ${ }^{1,3}$, Rizha Hardyansah ${ }^{3}$, \\ Ferik Antyo Agus Wibowo ${ }^{3}$ \\ ${ }^{1}$ Faculty of Mathematic and Natural Sciences, University of Brawijaya, Malang, Indonesia \\ ${ }^{2}$ Faculty of Fisheries and Marine Science, University of Brawijaya, Malang, Indonesia \\ ${ }^{3}$ Postgraduate School, University of Brawijaya, Malang, Indonesia
}

\begin{abstract}
A rural village, similar to other rural areas, has a need to be economically independent in cope with their sustainable economic growth. A unique value accompanied by good hospitality has been the main situation concerns with tourism. This paper discusses the assessment of attitudes and concerns of residents in the-only educational scout-based tourism village in Indonesia. Data for the study was collected by spreading the questionnaire directly to residents. Data collected through a direct survey. Attitudes were assessed by a 5-point strongly disagree and strongly agree scale on several questions implying residents' opinions on educational scout-based tourism and its impacts. The results showed great support for tourism. Residents have positive attitudes regarding tourism as they associate it to be important for their economic growth. The main concerns for residents in welcoming tourism are including their village community progress, better services in health and education, as well as the hope for the available market in their crafts products. However, the results also showed residents were not particularly assured of the user (tourists) money circulation and facilities benefit from the tourism activities occurred in their village, even though they support educational scout-based tourism development. It indicated a lack of self-confidence and trust issues towards the tourism manager. In this paper, a slight correlation between education and residents' attitudes towards tourism also discussed.
\end{abstract}

Keywords: confidence, educational tourism, Lebakharjo, trust.

\section{INTRODUCTION}

Lebakharjo, Ampelgading Malang is located in the south part of Malang county, East Java province, Indonesia. This village is unique with many historical sites, such as International Asia Pacific, World Scout Competition on Habitat, and second international Scouts Asia Pacific (COMDECA) in 1978. Those international activities have left many historical statues such as world peace statue and international scouts monument. Those events have been attended by the Indonesian republic at the time, President Soeharto. Thus, the house he left and other monuments indicating his presence at the time has become an important historical site for Indonesian people, more importantly for Indonesian scouts.

Scout in Indonesia has been developed even before its independence. Many scout related activities that occurred in Lebakharjo had been a special attraction to scouts members. Recent activity occurred on August $13^{\text {th }}-19^{\text {th }}, 2018$ in Lebakharjo, which was called National Karang Pamitran. This activity attended by approximately 10,000 participants from all over

\footnotetext{
Correspondence address:

Mufidah Afiyanti

Email : mufidahafiyanti@gmail.com

Address : Postgraduate School, University of Brawijaya, Mayjen Haryono 169, Malang 65145.
}

the archipelago. Participants come from the Branch Quarters, Regional Quarters, house group (Gudep), Indonesian Embassy (KBRI), Indonesian General Consulate (KJRI). They consist of Scouting Trustees, Scout Workers, Scouting Trainers, Heads of Scouting Education and Training Centers throughout Indonesia. This National Karang Pamitran suggests that the village existence has been very important to the scouts' communities in Indonesia [1]

Diverse results have been demonstrated in several studies regarding studies on resident's attitudes towards tourism development. Residence and life quality affected attitudes of residents on their attitudes and perspectives about tourism [2]. Other research also found that education level, age, gender, as well as socialcultural environment were factors that influenced the development of tourism [3]. Some studies showed factors such as sociodemographic having an impact on the residentss' attitudes towards tourism [4,5,6]. Meanwhile, others also found that recognized individual benefits from tourism affect residents' perceptions as well as attitudes towards the development of tourism $[7,8,9]$.

Community characteristics including the level of tourism development and the local economy dependency on tourism played an important role in building the residents' attitudes towards the 
development of tourism $[10,11,12]$. This study delivers the role of residents and perceptions of community preparedness on attitudes towards scout-based tourism. This study is important to find out the readiness and the acceptance of the villagers towards the conversion of village functions into educational scout-based tourism areas.

Lebakharjo, other than the scouts, also has been famous for its agricultural products, especially rice, coffee, and durian. It is also famous for its natural beautiful sceneries, such as black-sandy beaches, natural water springs, etc. However, despite those natural resources, the villagers' income is still very low (interview with village head). Thus, Lebakharjo moves forward on making Lebakharjo as the first scout-based village in Indonesia, along with its historical sites and value. It expected to increase the support for economic growth.

Many efforts conducted, such as building new roads, replanting durian as the icon of fruits in Lebakharjo, as well as have training for the villager to make new products from agricultural materials produced in the village (interview with village head). However, even though several efforts conducted to move forward to the tourism industry, how the residents' attitude towards this tourism was unknown.

The study investigated residents' attitudes towards scout-based tourism development in Lebakharjo village, Malang County, East Java, Indonesia. This study assessed how residents' attitudes vary with the respondent level of education and the duration of stay.

\section{MATERIAL AND METHOD}

Data collected through a structured questionnaire administered through a direct survey to a small number of residents (30 residents) in Lebakharjo village. Answeredquestionnaire papers were collected. The questionnaire papers including attitudes measured by a 5 point strongly disagree to strongly agree scale on a series of questions, soliciting residents' opinions on scouts-based tourism development and its perceived impacts. Residents' perceptions of community preparedness were measured by several items, grouped into four categories, as presented in Table 1.

Analysis techniques used included t-test and ANOVA. Educational background and stay duration were used as independent variables in cope with their correlation with attitudes and concerns towards scout-based tourism.

\section{RESULT AND DISCUSSION}

A total of 30 questionnaires were completed of, which $100 \%$ are residents from Lebakharjo. Most (93\%) of the residents were female, and about a very small part were male $(7 \%)$. The majority of the residents were over the age of 30 to 50 years old, with $30-40$ years as the mean age group. The average education levels of residents were junior and senior high school graduates.

\section{Residents attitudes towards scouts-based tourism}

Overall, the residents had positive attitudes and supportive of scout-based tourism development. It demonstrated by interpretation score observation on the Likert scale. The result showed that there were twelve positive questions regarding scout-based tourism However, results also show that residents are supportive of scout-based tourism development as long as they don't have to pay to fund it.

The lowest interpretation score based on Likert scale on positive statements was for the statement "Money issued by tourists does not come out of the village" and "Educational Tourism provides facilities both for tourists and village residents". Residents are not particularly assured of user money circulation and facilities benefit from the tourism activities occurred in their village, even though they support scoutbased tourism development.

Residents generally didn't agree with negative questions including that tourism would increase crime rates, endanger the noble values of the village community, interfere with village community activities, and damage their environment, indicating overall support for scout-based tourism. Table 1 explains the analysis of the mean scores taken from the result of questionnaires given to residents. Points 1-5 in the method were used in the questionnaires given to residents.

Overall, residents of Lebakharjo village are very supportive of scout-based tourism development. However, it is interesting to note that residents were supportive but not assure if tourists would spend their money most on their product. It may indicate that there is still a lack of confidence, neither in their product nor in attracting tourists. Based on a previous study [12], in a rural village, common threats of having village-based tourism are selfconfidence and lack of participation in village tourism development. 
Table 1. Likert Scale Score for Residents Attitudes towards Tourism

\begin{tabular}{|c|c|c|c|}
\hline \multicolumn{2}{|c|}{ Positive Questions } & \multirow{2}{*}{$\begin{array}{c}\text { Likert Scale Score } \\
112 \\
\end{array}$} & \multirow{2}{*}{$\begin{array}{c}\begin{array}{c}\text { Interpretation Score of } \\
\text { Observations (\%) }\end{array} \\
93.33 \\
\end{array}$} \\
\hline 1 & $\begin{array}{l}\text { If Lebakharjo becomes an educational tourism village, it will be } \\
\text { very good for the progress of the village community }\end{array}$ & & \\
\hline 2 & $\begin{array}{l}\text { I get benefited, if my village became an educational tourism } \\
\text { destination }\end{array}$ & 107 & 89.17 \\
\hline 3 & Educational tourism can create new jobs & 105 & 87.50 \\
\hline 4 & $\begin{array}{l}\text { Educational tourism can provide employment for youth in the } \\
\text { village }\end{array}$ & 108 & 90.00 \\
\hline 5 & $\begin{array}{l}\text { Educational tourism can increase the selling price of village } \\
\text { products }\end{array}$ & 107 & 89.17 \\
\hline 6 & $\begin{array}{l}\text { Educational tourism can help village communities to get better } \\
\text { services (health, education, etc.) }\end{array}$ & 112 & 93.33 \\
\hline 7 & $\begin{array}{l}\text { Educational tourism can increase the production of crafts } \\
\text { (handicrafts, typical foods, etc.) }\end{array}$ & 113 & 94.17 \\
\hline 8 & $\begin{array}{l}\text { Educational tourism can increase the use of natural resources } \\
\text { (wood, fish, etc.) by the community }\end{array}$ & 106 & 88.33 \\
\hline 9 & $\begin{array}{l}\text { Educational tourism can Rural communities can manage tourism } \\
\text { in the village }\end{array}$ & 102 & 85.00 \\
\hline 10 & Money issued by tourists does not come out of the village & 84 & 70.00 \\
\hline 11 & $\begin{array}{l}\text { Educational Tourism provides facilities both for tourists and } \\
\text { village residents }\end{array}$ & 84 & 70.00 \\
\hline 12 & Educational tourism can increase entrepreneurship in the village & 108 & 90.00 \\
\hline \multicolumn{4}{|c|}{ Negative Questions } \\
\hline 1 & Educational tourism can increase crime rates & 57 & 47.50 \\
\hline 2 & $\begin{array}{l}\text { Educational tourism can endanger the noble values of the } \\
\text { village community }\end{array}$ & 52 & 43.33 \\
\hline 3 & $\begin{array}{l}\text { Educational tourism can interfere with village community } \\
\text { activities }\end{array}$ & 49 & 40.83 \\
\hline 4 & Educational tourism can damage the environment & 47 & 39.17 \\
\hline
\end{tabular}

The implication of this is that residents have to improve their products, which are in high and unique value, which also functions as a symbol for a particular tourist attraction. Other than that, it is also interesting that "Educational Tourism provides facilities both for tourists and village residents" got low mark on this survey. It may indicate that there still a lack of trust from residents towards the manager of educational scout-based tourism.

Based on another study on the public trust towards the tourism manager in Mauritius, the results demonstrated that trust is strongly related to the residents' support for political and authorities, in this case, manager of tourism [14]. Based on our result, this may imply that there is still a trust issue in the relation between the manager of educational scout-based tourism and residents in Lebakharjo. Building trust and confidence may become a concern to enhance the positive attitudes of residents towards educational scout-based tourism development.

\section{Education is slightly affect the attitude and concern towards tourism}

Residents in villages commonly have a relatively low educational level background. In this study, we also observed the correlation between residents' educational background in cope with attitudes and concerns towards educational scout-based tourism in Lebakharjo village. Table 2 demonstrated that the correlation value was 0.023 . It shows that the correlation between educational variables as an independent variable with public attitudes and concerns about tourism villages as the dependent variable is not significantly correlated.

Table 2. Regression analysis for education level and duration stay of residents towards attitudes and concerns regarding educational scoutbased tourism

\begin{tabular}{|c|c|c|c|c|}
\hline & & $\begin{array}{l}\text { communities } \\
\text { attitude \& } \\
\text { concern to } \\
\text { tourism }\end{array}$ & Education & $\begin{array}{c}\text { Stay } \\
\text { duration }\end{array}$ \\
\hline \multirow[t]{2}{*}{$\begin{array}{l}\text { Pearson } \\
\text { Correlation }\end{array}$} & Education & .023 & 1.000 & -.382 \\
\hline & $\begin{array}{l}\text { Stay } \\
\text { duration }\end{array}$ & -.010 & -.382 & 1.000 \\
\hline \multirow[t]{2}{*}{$\begin{array}{l}\text { Sig. (1- } \\
\text { tailed) }\end{array}$} & Education & .452 & . & .019 \\
\hline & $\begin{array}{l}\text { Stay } \\
\text { duration }\end{array}$ & .480 & .019 & \\
\hline
\end{tabular}


The correlation value that is closer to 0 indicates that the correlation between these variables is weak $(p=0.452, p>0.05)$ but still has a causal relationship. The education level of the majority of middle and high school people shows that education about tourism villages is still relatively minimal. Therefore, knowledge from the community regarding tourism villages is still limited, but the community believes that when Lebakharjo Village is made into a tourist village, it will bring great benefits to the environment and society.

In addition to the correlation with education, the correlation between length of stay, attitudes and concerns of the community, regarding tourism villages, showed a negative correlation with a correlation value of -0.010 . As stated before, the sig correlation that was closer to 0 showed a weak correlation $(p=0.480, p>0.05)$.

Length of stay may not necessarily affect the attitude and attention to get to the tourist village. It can be due to the fact that the majority of the population already has a fixed income with a definite monthly income, so that people prefer to focus on work rather than making a destination and focusing on tourism development.

Community empowerment through scouts activities which has been continuously conducted in Lebakharjo since 1978, may have positive impact in improving attitude and concern, thus even though educational background are not high, residents still have positive attitudes towards tourism. Our result is in accordance with previous result in Uganda, it demonstrated that community empowerment has a great impact in participation and involvement of residents in tourism growth in developing country [15].

\section{CONCLUSION}

Residents of Lebakharjo village are very supportive towards educational scout-based tourism development. However, lack of confidence and trust to authorities are still need improvement. Educational level has slightly correlates with the residents attitudes. Meanwhile no significant correlation between duration of stay and the residents attitudes. Future research shall focus on observing residents attitudes to determine if changes on tourism development and economic growth in the community. Those will be of concerns to different stakeholders, as well as the residents themselves to build the verge of support for development of tourism and growth in the community.

\section{Acknowledgement}

We thank the Village head and respondents of Lebakharjo for all data and their assistances in completing this community service activity. This activity is funded by Doctor Dedication Program 2018, Center of Research and Community Services (LPPM), University of Brawijaya.

\section{REFERENCES}

[1] Malang Post. 2018. Lebakharjo tuan rumah Karang Pamitran nasional. Available at: https://www.malang-post.com/berita/ malang-raya/lebakharjo-tuan-rumahkarang -pamitran-nasional-2018.

[2] Hao, H., P. Long, and J. Kleckley. 2011. Factors predicting homeowners' attitudes toward tourism: A case of a coastal resort community. Journal of Travel Research 50(6), 627-640.

[3] Muresan, I. C., C. F. Oroian, R. Harun, F. H. Arion, A. Porutiu, G. O. Chiciudean, A. Todea, and R. Lilie. 2016. Local residents' attitudes towards sustainable rural tourism development. Sustainability 8(1), 100.

[4] McGehee, N. G. and K. L. Andereck. 2004. Factors predicting rural residentss' support of tourism. Journal of Travel Research 43, 131-140.

[5] Lui, J. C., and T. Var. 1986. Residents attitudes toward tourism impacts in Hawaii. Annals of Tourism Research 13(2), 193-214.

[6] Um, S. and J. L. Crompton. 1987. Measuring residentss' attachment levels in a host community. Journal of Travel Research 26(1), 27-29.

[7] Deccio, C. and S. Baloglu. 2002. Nonhost community residents reactions to the 2002 Winter Olympics: The spillover impacts. Journal of Travel Research 41(2), 46-56.

[8] Perdue, R. R., P. T. Long, and L. Allen. 1990. Residents support for tourism development. Annals of Tourism Research 17(4), 586-599.

[9] Jurowski, C., M. Uysal, and D. R. Williams. 1997. A theoretical analysis of host community residents reactions to tourism. Journal of Travel Research 34(2), 3-11.

[10] Gursoy, D. and G. Rutherford. 2004. Host attitudes toward tourism: An improved structural model. Annals of Tourism Research 31(3), 495-516.

[11] Butler, R. 1980. The concept of a tourist area life cycle of evolution: Implications for 
management of resources. Canadian Geographer 24(1), 5-12.

[12] Long, P., R. Perdue, and L. Allen. 1990. Rural residents tourism perceptions and attitudes by community level of tourism. Journal of Travel Research 28(3), 3-9.

[13] Hidayat A., M. Rahmanita, and $H$. Hermantoro. 2017. Community empowerment in Plempoh Cultural Tourism Village. TRJ Tourism Research Journal 1(1), 98-116.

[14] Nunkoo, R., H. Ramkissoon, and D. Gursoy. 2012. Public trust in tourism institutions. Annals of Tourism Research 39(3), 15381564.

[15] Tukamushaba, E. K. and R. N. Oche. 2011. Tourism training and education, Community empowerment and Participation in tourism planning and development. A case of Uganda. Journal of Tourism XII (1). 